\title{
LA CAPILLA Y EL RETABLO DE LA VENERABLE ORDEN TERCERA DEL CONVENTO DE CAPUCHINOS DE SEVILLA
}

\author{
THE CHAPEL AND THE ALTARPIECE \\ OF THE VENERABLE THIRD ORDER \\ AT THE CONVENT OF CAPUCHIN IN SEVILLE
}

\author{
Álvaro Cabezas García \\ Grupo de investigación HUM-317: Laraña. España \\ ORCID: 0000-0001-9675-8964 \\ alvarocabezasgarcia@gmail.com \\ Álvaro Recio Mir \\ Universidad de Sevilla. España \\ ORCID: 0000-0001-7874-5625 \\ alvarorecio@us.es
}

Análisis de la capilla de la Venerable Orden Tercera del convento de Capuchinos de Sevilla, construida en el siglo XVIII, y del retablo de la misma, obra de Felipe Fernández del Castillo y que se creía desaparecido.

Palabras clave: Venerable Orden Tercera del convento de capuchinos de Sevilla; capilla; retablo; Felipe Fernández del Castillo; siglo XVIII.

Analysis of the Chapel of the Venerable Third Order at the Capuchin Convent in Seville, built in the $18^{\text {th }}$ century, and its altarpiece, by Felipe Fernández del Castillo and believed to have disappeared.

Keywords: Venerable Third Order at the Convent of Capuchins in Seville; chapel; altarpiece; Felipe Fernández del Castillo; $18^{\text {th }}$ century. 


\section{LA VENERABLE ORDEN TERCERA Y SU CAPILLA}

La enorme riqueza de sus conjuntos monásticos, muchos de ellos aún conservados, es una de las facetas menos estudiadas por la historia del arte hispalense. Dentro de este ámbito, uno de los conventos menos atendidos por la investigación es el de Capuchinos, con la única excepción del culminante conjunto de pinturas que realizó Murillo para él ${ }^{1}$. Por ello es nuestra intención en adelante aportar alguna luz sobre la capilla y los retablos de su Venerable Orden Tercera, levantados en el siglo XVIII y completamente inéditos, lo que pone en evidencia, una vez más, la sorprendente riqueza de la escuela artística hispalense que sigue deparando sorpresas como esta.

El estudio de las venerables órdenes terceras está aún por acometer, pese a que alguna investigación al respecto afirma que su número en España a principios del siglo XX superaba las ochocientas. De ellas, casi trescientas estaban vinculadas a los franciscanos y en torno a doscientas cincuenta a los capuchinos. Las actividades más frecuentes que desarrollaban estas asociaciones de seglares eran la asistencia a los enfermos, reuniones dominicales, organización de conferencias y otros ejercicios piadosos, entre los que destacaban el culto a ciertas devociones, en ocasiones de singular popularidad ${ }^{2}$.

Eso último parece que fue el germen que creó la necesidad de levantar en el compás del convento de Capuchinos de Sevilla, en disposición perpendicular a su iglesia, una capilla para su Venerable Orden Tercera. Configurada como una elevada, alargada y sencilla nave, sigue el modelo de las denominadas iglesias de cajón, siendo de una sencillez estructural absoluta y respondiendo a lo que acertadamente se ha denominado "iglesia mínima". Tal espacio fue cubierto por una bóveda de cañón con lunetos, dividida en tres tramos, con coro elevado a los pies, más una cabecera cupulada a la que se añadió un camarín. A ello hay que sumar una sala capitular y un jardín que en origen debió de ser una de las huertas con las que contaba el cenobio ${ }^{4}$.

La fortuna crítica de esta construcción ha sido hasta ahora muy escasa. La mencionó por vez primera González de León a mediados del siglo XIX en su clásica Noticia artística, donde, con su característica mentalidad neoclásica, dijo de ella que "es pequeña, tiene tres altares de mala construcción", a lo que aún apostilló "nada hay más que ver en la citada capilla"

${ }^{1}$ La última y más completa aportación al respecto es AA.VV., 2017.

2 En cuanto a estas instituciones, remitimos a Peláez del Rosal, 2006. Otras capillas sevillanas de órdenes terceras son estudiadas en Roda Peña, 2013: 491-513; 2018: 237-263. Ruiz Barrera, 2014: 433-446; 2016.

${ }^{3}$ Pérez del Prado, 2000.

${ }^{4}$ Sobre la correspondiente cofradía, remitimos a Valiente Romero/Martínez Laguna, 2008: 11 .

5 González de León, 1844: 508. 
Algo más abundó Justino Matute poco después en sus Anales decimonónicos, en los que indicó que en 1760, en concreto, el 21 de junio, "la Orden Tercera del convento de Capuchinos, con su reverenda comunidad, celebró muy solemne procesión con la imagen de nuestra Señora en hábito de Pastora, cuya advocación tuvo su origen en un hijo del mismo convento, la cual fue colocada en la nueva capilla de los Terceros, habiéndose aquella noche quemado en su obsequio en el inmediato campo un gran castillo de pólvora y continuaron fiestas por la mañana y tarde los tres días siguientes" 6 .

A lo anterior solo resta añadir las referencias aportadas por el padre Ardales, cuya monumental y clásica obra La Divina Pastora y el beato Diego José de Cádiz es referencia imprescindible sobre todo lo relativo al convento sevillano de capuchinos y que iremos recogiendo en adelante ${ }^{7}$.

La mayor parte de la documentación referida, no solo al inmueble sino a la propia corporación religiosa, se perdió durante la invasión francesa, pero el cronista de la orden capuchina fray Ángel de León (1741-1814) escribió a principios del siglo XIX una detallada relación que daba cuenta de la historia de la Venerable Orden Tercera de Penitencia ${ }^{8}$. Impulsada por el padre fray Antonio de Arahal, se fundó el 1 de enero de 1706 con licencia y autoridad del provincial Isidoro Francisco de Bruselas, quien nombró como primer comisario visitador al venerable padre fray Feliciano de Sevilla ${ }^{9}$. Dicho provincial, de visita en el convento capuchino, confirmó con especial decreto el Venerable Orden Tercero, como también en ocasiones se le llamaba, el 26 de marzo de 1706. Durante sus primeros años parece que tuvo escasa actividad la referida corporación, que hasta $1715 \mathrm{se}$ ubicó en la capilla de San Francisco de la iglesia del convento, donde estaba la imagen del santo "abrazado con Cristo crucificado", en clara referencia al cuadro de San Francisco abrazando a Cristo en la cruz de Murillo (en la actualidad en el Museo de Bellas Artes de Sevilla, hacia 1665-1668), entonces al inicio de la nave del evangelio ${ }^{10}$. Esta circunstancia "movió a los hermanos terceros para formar su esclavitud viendo el material ejemplar del Santo Padre San Francisco abrazado con Cristo en la cruz, imprimiéndole sus llagas y dolores" ${ }^{11}$.

${ }^{6}$ Matute y Gaviria, 1887: 170-171.

7 De Ardales, 1949.

${ }^{8}$ Archivo Histórico Provincial de los Capuchinos de Andalucía (AHPCA), leg. 323, 1803-1805, doc. 1, Libro primero de historia, o fastos del convento de menores capuchinos de nuestro señor padre San Francisco, extramuros de la ciudad de Sevilla, por sucesión de años para gobierno de esta santa comunidad y casos ejemplares que den luz para los que acaecieren en lo futuro. Lo escribía de orden superior fray Ángel de León, año de 1805, "Capilla del Venerable Orden Tercero, su fundación y progresos, etc.", ff. $27 \mathrm{v}-33 \mathrm{v}$.

9 AHPCA, leg. 323, 1803-1805, doc. 1, Libro primero..., ff. 27v-28r.

${ }^{10}$ Para conocer el contexto y programa iconográfico de la serie que Murillo realizó para los capuchinos de Sevilla, Martínez del Valle/Valdivieso González, 2009: 123-128.

${ }^{11}$ AHPCA, leg. 323, 1803-1805, doc. 1, Libro primero..., f. 31r. 
El 13 de diciembre de 1714, siendo comisario fray Francisco de Málaga, se admitieron por hermanos y cofrades a todos los religiosos profesos, novicios y donados que se integraban en la comunidad capuchina de Sevilla, para que participaran de los sufragios y distinciones que en la Venerable Orden Tercera acostumbraban a hacer los hermanos en vida y en muerte, "lo cual se observó en los primeros años con grande armonía; después hasta el presente ha ido decayendo hasta quedar en solo el ejercicio que la comunidad tiene para la conservación espiritual de este Venerable Orden Tercero" 12.

La referida incorporación de la comunidad capuchina debió de impulsar el desarrollo de la orden tercera, que quiso dotarse de un espacio propio y adecuado, de manera que se comenzó a construir la actual capilla en el atrio del convento $^{13}$, siendo bendecida el 19 de abril de 1725 por el padre presidente del mismo, fray Francisco de Constantina. El domingo siguiente, 22 de abril, tuvo lugar en ese recinto la primera misa, ofrecida entonces por el padre comisario visitador, fray Adrián José de Sevilla ${ }^{14}$. Desde ese momento recibió culto en el altar mayor como titular de la corporación una imagen donada por una hermana con la advocación de Nuestra Señora de los Ángeles ${ }^{15}$ (Figuras 1-3).

Si bien en el espacio que originalmente habían destinado para el culto en la iglesia formaron una esclavitud dedicada a San Francisco, en su recién levantada capilla quisieron hacer lo mismo, fundando en 1726 una "esclavitud al Santísimo Cristo de Burgos, cuya imagen fue dada por uno de sus hermanos a este Venerable Orden, con el cargo que se venere entre los mismos hermanos, siendo estos los esclavos y no otros, como también que no pueda separarse dicha esclavitud del venerable orden haciendo hermanos aparte, sino que lo mismo sea ser tercero profeso, que ser esclavo del Santísimo Cristo de Burgos, pues esto solo será para enfervorizar a más inclinación y aplicación a su capilla, y a este Divino Señor en que confiamos y fiamos todo el buen éxito de este Venerable Orden como a nuestro amo, dueño y señor" ${ }^{16}$. La corporación estaba presidida por el comisario interino, fray Gregorio de Almonaster, y el ministro era el hermano Juan Martín Rodríguez. Para todo ello, una imagen de Cristo crucificado, de tamaño natural, fue colocada en la propia capilla ${ }^{17}$.

A buen seguro, y con objeto de contar con mayor espacio para ofrecer un culto más adecuado tanto a la Virgen de los Ángeles como al Cristo de Burgos, fue necesario ampliar el espacio de la capilla, por lo que el 14 de abril de 1733 los capuchinos le concedieron a la orden tercera diez varas y un cuadro de terreno

12 AHPCA, leg. 323, 1803-1805, doc. 1, Libro primero..., f. 28v.

13 AHPCA, leg. 323, 1803-1805, doc. 1, Libro primero..., "Estreno de la nueva capilla del Venerable Orden Tercero", f. 30r.

${ }^{14}$ De Ardales, 1949: 149.

15 AHPCA, leg. 323, 1803-1805, doc. 1, Libro primero..., f. 31r.

16 AHPCA, leg. 323, 1803-1805, doc. 1, Libro primero..., f. 31r.

${ }_{17}$ AHPCA, leg. 323, 1803-1805, doc. 1, Libro primero..., f. 31 r. 
"para labrar presbiterio y agrandar la capilla de los terceros y camarín a Nuestra Señora de los Ángeles en el sitio de la viña"18. Esta ampliación se alargó considerablemente en el tiempo ${ }^{19}$, de manera que todavía en 1755 "se continuaba con ardor la obra de la capilla de los Terceros" 20 .

La siguiente referencia documental señala que, por fin, la mañana del sábado 21 de junio de 1760, "reedificada y concluido el ensanche de la capilla de los terceros", fue bendecida por el padre guardián Luis de Sestri, con asistencia de la comunidad y lógicamente de la Venerable Orden Tercera, añadiéndose que "por la tarde se hizo la procesión para restituir las imágenes de la capilla, saliendo de mañana y para por el pórtico y campo hasta la pila o alcobilla del agua, con el Santísimo Sacramento, la Divina Pastora, Nuestro Padre San Francisco y San Fidel de Sigmaringa. En la noche hubo fuegos artificiales, luminarias y velada" 21 . Para todo ello se obtuvo la correspondiente licencia por parte del asistente de la ciudad, el marqués de Monte Real, con objeto de que la puerta de Córdoba estuviera abierta y el público pudiera acceder con facilidad a ella ${ }^{22}$. Al día siguiente, domingo 22 de junio, se hizo la fiesta de la comunidad de capuchinos, predicada por fray Salvador de Sevilla, que vino del convento de Écija. El lunes 23 se celebró otra misa, en esta ocasión predicada por el doctor don Antonio de Cárdenas, hermano tercero de la Observancia. Por último, el martes 24, día de San Juan Bautista, predicó el comisario, fray Antonio de Sevilla ${ }^{23}$. A pesar de tan solemne y fastuoso estreno, al año siguiente fue necesario apuntalar la capilla ${ }^{24}$, lo que

18 AHPCA, leg. 323, 1803-1805, doc. 1, Libro primero..., f. 31r. De Ardales, 1949: 149.

19 Ello pudiera ser debido a tensiones entre la comunidad y la orden tercera por compartir espacio, como se desprenden de la propuesta realizada el 21 de junio de 1750 por el comisario, fray Francisco de Lucena, a la orden de parte del padre guardián, fray Antonio de Alcalá, de que "cediese el sitio que tenía cercado para agrandar su capilla y ahuecar el camarín, respondió el Orden Tercero que no tenían ánimo para cederlo". AHPCA, leg. 323, 1803-1805, doc. 1, Libro primero..., f. 31r.

${ }^{20}$ Durante estas obras se trasladaron las imágenes de la orden a la capilla de las Santas Justa y Rufina del convento, mientras que la capilla que los hermanos terceros utilizaron "para dar hábitos y profesiones" fue la de San Francisco, como en sus momentos fundacionales. De Ardales, 1949: 149.

${ }^{21}$ Es muy posible que esta imagen fuera la que se utilizó para las fiestas que celebró la comunidad de capuchinos de Sevilla con motivo de la canonización de San Fidel de Sigmaringa y José de Leonisa en 1748. Cabezas García, 2019: 391-402.

22 Cabezas García, 2019: 391-402.

23 "El primer día dio para un principio a la comunidad, quedando empeñado el Venerable Orden Tercero después de la obra y estreno de la capilla en 6.630 reales de vellón". AHPCA, leg. 323, 1803-1805, doc. 1, Libro primero..., f. 30r.

24 "Inmediatamente después del estreno se reconoció flaqueza en los cimientos de la obra nueva de la capilla, y en 6 de septiembre del año 1761 se determinó poner entibos para su seguridad”. AHPCA, leg. 323, 1803-1805, doc. 1, Libro primero..., f. 30v. 
parece indicar que se trataba de una construcción modesta, que como veremos en adelante ha requerido de diversas intervenciones a lo largo de su historia.

La documentación consultada en ningún caso hace referencia a la autoría de la misma, ni da ninguna pista al respecto, por lo que debe ser considerada obra anónima, levantada por algún modesto albañil sevillano de la plenitud barroca. $\mathrm{Su}$ carácter fundamentalmente desornamentado - apenas cabría referir en tal sentido las sencillas ménsulas de las que parten los arcos fajones de su bóveda-, tampoco permite sugerir atribuciones acerca de esta ignota autoría.

En cualquier caso, esta capilla sirvió como espacio auxiliar de la vecina comunidad de capuchinos en varias ocasiones, como cuando, tras los efectos de la importante riada que sufrió la ciudad a finales de 1783 y comienzos del siguiente, el Santísimo Sacramento de la iglesia fue colocado "en el coro alto y bajo, y en la capilla del noviciado" 25 , hasta que se tomó la decisión de trasladarlo a la capilla de la orden tercera en marzo de 1785, donde recibió culto hasta septiembre de ese mismo año, cuando, por motivo de las celebraciones organizadas por la beatificación de Lorenzo de Brindis, los capuchinos se vieron obligados a adecentar adecuadamente su iglesia ${ }^{26}$.

Hubo un nuevo intento de ampliar el perímetro de la capilla: en mayo de 1799 el provincial, fray Jerónimo de Cabra, concedió a la orden "un pedazo de terreno para ensanchar las habitaciones de su capilla", y, aunque la comunidad no estaba conforme, las obras empezaron. Sin embargo, el padre general, Nicolás de Busti1lo, paralizó la obra poco después por "por inútil, dañosa y superflua" 27.

De nuevo, en 1813 y tras la invasión francesa, los religiosos capuchinos celebraron sus cultos en la capilla de la orden tercera, ya que su iglesia se estaba reparando $^{28}$. No obstante, este recinto debía de estar entonces por completo desnudo en su interior, ya que ese mismo año se apresuraron a habilitarlo, poniendo en él al Santísimo Sacramento, que vino de la parroquia de San Gil. De igual modo, se trajeron de la de San Julián "los tres retablos, imágenes y demás utensilios que el Venerable Orden había depositado en aquella iglesia con orden del gobierno francés" 29 .

${ }_{25}$ AHPCA, leg. 323, 1803-1805, doc. 1, Libro primero..., f. 32r.

${ }^{26}$ Sobre estas fiestas y el ornato efímero de la iglesia, Cabezas García, 2018: 353-370.

${ }^{27}$ AHPCA, leg. 323, 1803-1805, doc. 1, Libro primero..., f. 32v.

28 AHPCA, leg. 323, 1803-1805, doc. 2, Libro segundo de historia, o fastos del convento de menores capuchinos de nuestro señor padre San Francisco, extramuros de la ciudad de Sevilla, por sucesión de años para gobierno de esta santa comunidad y casos ejemplares que den luz para los que acaecieren en lo futuro. Lo escribía de orden superior fray Ángel de León, año de 1805 , f. $231 \mathrm{r}$.

${ }_{29}$ Algunos de estos utensilios serían un cáliz y un copón. Valiente Romero/Martínez Laguna, 2008: 13-14. 
Tras los delicados avatares por los que pasó el convento en el siglo XIX, tanto la referida invasión francesa como las diversas desamortizaciones que sufrió, sabemos que la capilla de su Venerable Orden Tercera fue profundamente restaurada en 1891, poco después del definitivo regreso de los capuchinos en $1889^{30}$. En tal sentido, en la junta general de hermanos celebrada en la sala capitular anexa a la capilla el 17 de junio de ese último año el padre provincial, fray Fermín de Velilla, manifestó "el deseo de establecer una escuela gratuita para los niños pobres con el fin de formar en sus tiernos corazones el santo temor de Dios, al mismo tiempo que ilustrar sus entendimientos con la verdadera ciencia cristiana, para lo cual suplicaba a la Venerable Orden Tercera le prestase el local de nuestra sala capitular, sala del capiller y el adjunto jardín o corral", a lo que accedieron, a condición de que quedase claro que todo era propiedad de la corporación ${ }^{31}$.

Solo unos días después, el 29 de junio de 1889, en una nueva junta se acordó nombrar una comisión para pedir limosna destinada a "la restauración de la capilla que se encuentra hoy en estado ruinoso" 32 . Para ello, en la reunión del 5 de julio, se presentaron los contratos de los maestros albañil y carpintero. El primero lo firmaban José Ferrer y Giménez, que se comprometía a suministrar todos los materiales necesarios, y Manuel García, el cual llevaría a cabo la mano de obra "en la capilla y sala adjunta de la V.O.T." por 2.500 reales, "pagaderos mitad cuando esté la armadura colocada sobre los muros y la otra mitad al final de la obra". La documentación especifica pormenorizadamente las labores a realizar ${ }^{33}$.

${ }^{30}$ Valiente Romero/Martínez Laguna, 2008: 12-14.

31 AHPCA, leg. 252, doc. 1, Libro cuarto de acuerdos tomados por el V.O.T. de penitencia de capuchinos en esta ciudad, 1881-1912, f. 24r-v.

${ }_{32}$ AHPCA, leg. 252, doc. 1, Libro cuarto..., f. 30r.

${ }^{33}$ En concreto: " $1^{\mathrm{a}}$ desmontar la armadura vieja; $2^{\mathrm{a}}$ componer los muros para poner la nueva, recalsarlos, poner llaves de material en las rajas de los muros donde las necesiten y levantar o crecer dicho muro en la trasera de la capilla; $3^{\mathrm{a}}$ poner los formeros; $4^{\mathrm{a}}$ tejar con buenas y sanas tejas, gemelándolas tres pulgadas, embarilladas con cal y arena y usar de mescla en toda la obra con dos de tierra y una de cal buena de hornos continuos y en la paredes de cal de la tierra; $5^{\text {a }}$ poner una moldura en el vuelo del tejado de dicha capi1la; $6^{\text {a }}$ blanquear los caballetes, la capilla y sala adjunta con cal de Morón y la bóveda con yeso blanco; $7^{\mathrm{a}}$ quitar la tierra de la bóveda, resanarla quitándole media vara de ancho por arriba y por abajo del yeso viejo y ponerlo nuevo blanco; $8^{\mathrm{a}}$ quitar los escombros que resulten de la obra, depositándolos fuera del local de la V.O.T.; $9^{a}$ poner andamios y suplir los jornales, hasta el primer cobro; $10^{\mathrm{a}}$ permito se ponga un oficial de la confianza de la V.O.T. y costado por mi, con el objetivo de inspeccionar las obras y trabajando al mismo tiempo y igualmente los podrán inspeccionar los que tengan a bien la V.O.T.; $11^{\mathrm{a}}$ seremos responsables de todos los gastos y perjuicios que se originen, materiales y judiciales, por las faltas de cumplimiento de algunas de estas condiciones". AHPCA, leg. 252, doc. 1, Libro cuarto..., ff. 30v-31r. 
Por su parte, el maestro carpintero que intervendría en la empresa sería Juan Vélez Torres, que vivía en el número 40 de la cercana calle Enladrillada y que se comprometía a hacer y colocar una armadura nueva por la cantidad de 3.400 reales "en la misma forma y condiciones que indica el adjunto plan" 34 , dibujo no conservado.

Como colofón de esta profunda reconstrucción de 1896 y "en vista de que han desaparecido en la época azarosa de la invasión francesa varios libros y documentos pertenecientes a esta V.O.T. y entre ellos el que acreditaba la propiedad de la misma V.O. de la capilla, sala capitular y demás dependencias anexas, edificadas por esta V.O, en el año de 1725 y reedificadas en el de 1891 y considerando la necesidad de poseer algún documento que acredite sus derechos ha acordado, con la venia y autorización del muy reverendo padre provincial fray Ambrosio de Valencina, formar un expediente posesorio en el que conste que esta Venerable Orden Tercera edificó a su costa la referida capilla, habitaciones adjuntas y jardín y que viene poseyéndolo y sosteniéndolo y conservando este edificio sin interrupción alguna desde la referida época de su edificación" 35 .

En tal momento y en el marco de esta reconstrucción se debieron de añadir las ingenuas pinturas con las que aún en parte cuenta la capilla. Representan emblemas

34 " 1 a la armadura llevara siete formeros herrados con los anchos y gruesos siguientes

$\begin{array}{ll}\text { Pulgadas } & \text { centímetros } \\ 10 \text { por } 3 \frac{1 / 4}{4} & \text { o sea } 23.7 \\ 9 \text { por } 3 \frac{1}{4} & \text { o sea } 21.7 \\ 41 / 2 \text { por } 3 \frac{1}{4} & \text { o sea } 10 \\ 3 / 4 & \text { encintadas } \\ 2 \text { por } 1 / 3 & \end{array}$

Tirantes, alfardas y pendolones

Solerías

Correas y tornapuntas

La tablazón de hilo al medio

Herraje ancho

$2^{\mathrm{a}}$ la armadura será de pino de Flandes, sana y limpia, los tirantes de los muros quedarán en su sitio añadiéndoles lo que le falte para jansar el muro llevando fuera una cruceta.

$3^{\mathrm{a}}$ la armadura que se desmonta quedará a mi favor como el herraje que contenga.

$4^{\mathrm{a}}$ me comprometo a trabajar diez días en las composturas del techo de la sala adjunta, compostura de puertas, etc. y si faltaran jornales serán pagados a demás por la V.O.T. y si sobrase serán descontados.

$5^{\text {a }}$ si al desmontar el techo de la sala hubiera dos o veinte palos que no pudieren servir se cambiarán con los de la armadura que estuvieren mejores.

$6^{\mathrm{a}}$ el pago de dicho trabajo se hará en tres plazos el $1^{\circ}$ al terminar el trabajo de la armadura se me abonarán 1700 reales, a los cuatro meses 800 reales y a los siete meses de terminada la obra lo restante.

$7^{\mathrm{a}}$ quedo responsable a los daños y perjuicios materiales y judiciales que resultaren de la falta de alguna de las anteriores condiciones". AHPCA, leg. 252, doc. 1, Libro cuarto..., ff. $31 v-32 r$.

${ }^{35}$ AHPCA, leg. 252, doc. 1, Libro cuarto..., f. 54r. 
marianos en las pechinas de la cúpula y un paisaje, prácticamente desaparecido, en el camarín para enmarcar a la Divina Pastora que lo presidía ${ }^{36}$.

En los años siguientes a la referida reconstrucción decimonónica, aún se registran labores de conservación y mejora en el recinto. Así, en 1895, se acordó "hacer la obra de reparos en el almacén y jardín y recorrer los tejados". De igual modo, en 1898, el hermano Miguel Cabrera donó "dos arañas de cristal para velas con intención de que sean colocadas delante del altar mayor de nuestra capilla a ambos lados del camarín de la Divina Pastora, siendo asimismo voluntad expresa del donante que dichas arañas no se presten a nadie ni salgan por ningún concepto de nuestra capilla" 37 .

Por último, cabe señalar que a mediados del siglo XX esta capilla dejó de tener culto y fue empleada como almacén de la imprenta de los capuchinos, momento en el que su coro fue convertido en despacho. A finales de dicho siglo, la capilla fue pintada y reabierta al culto, encontrándose por fortuna en nuestros días en buen estado y en uso, tanto por la comunidad capuchina como por la propia Venerable Orden Tercera ${ }^{38}$.

\section{LOS RETABLOS}

Ya señalamos que solo González de León mencionó los retablos de la capilla de la Venerable Orden Tercera de Capuchinos, a los que calificó como obras de mala construcción. A ello añadió que el principal lo presidía una Divina Pastora, "hechura de mérito del acreditado D. Cristóbal Ramos"39.

El retablo mayor, de 7,5 por 4,9 metros aproximadamente, fue documentado por Heliodoro Sancho Corbacho en 1934, cuando publicó el contrato por el que Felipe Fernández del Castillo se comprometía a su hechura el 6 de marzo de $1759^{40}$. Las cláusulas del mismo son las habituales al respecto, señalando que su autor se comprometía a hacerlo "en todo arte y perfección, arreglado a un diseño

${ }^{36}$ Agradecemos al archivero del convento, nuestro colega Antonio Valiente Romero, que nos mostrase las fotografías de estas pinturas y su colaboración en la realización de esta investigación. Agradecimiento que hacemos extensivo a nuestro colega el profesor Pedro Martínez Lara, autor de las fotografías 4, 6 y 7 que ilustran este artículo.

${ }^{37}$ AHPCA, leg. 252, doc. 1, Libro cuarto..., ff. 50 y 68, respectivamente.

38 También en ese momento fue cegada su originaria sacristía, en su cabecera, y habilitada con dicha función una habitación que se abre a mitad de la capilla.

${ }^{39}$ González de León, 1844: 508. Es muy posible que se trate de la conservada en el propio convento y publicada por Román Villalón, 2019: 124, fig. 7.

${ }^{40}$ La decisión se había tomado unas semanas antes en el seno de la corporación: "En 18 de febrero de 1759 se determinó hacer retablo mayor de la capilla de los Terceros, y se ajustó en 6.500 reales de vellón, siendo comisario el padre fray Juan de Villafranca". AHPCA, leg. 323, 1803-1805, doc. 1, Libro primero..., f. 31v. 
que a este fin se a formado, que rubricado del presente escribano público tengo en mi poder, el qual tengo de dar acabado en la forma dicha y a vista y parecer de inteligentes que nombre dicha Venerable Orden para fin de maio deste presente año y la orden ha de conducirlo por su quenta y costa desde mis casas a la dicha capilla, siendo como a de ser de la mía el ponerlo en ella y dexarlo fijado en la pared y sitio correspondiente, administrándome tan solamente para ello un peón y no otra cosa alguna y la dicha Venerable hermandad a de ser obligada a darme por todo ello seis mil reales... dos mil quinientos para empesarla"41.

Este retablo se creía desaparecido en los varios estudios que con posterioridad han tratado la actividad artística de Felipe Fernández del Castillo ${ }^{42}$. No obstante, se conserva in situ, lo que ha podido ser comprobado una vez que la capilla ha sido despejada y devuelta al culto. Lo que no se ha conservado ha sido su traza, referida en el contrato. No obstante, se da la circunstancia de que recientemente se ha publicado otra traza de Felipe Fernández del Castillo, en concreto la que hizo muy poco antes para el retablo mayor de la parroquia sevillana de San Nicolás ${ }^{43}$. Tan interesante dibujo, que requeriría de un análisis acorde a su importancia, muestra las mismas características estilísticas que el que ahora nos ocupa, con las lógicas diferencias entre una obra de cierto empeño, como es la reflejada en dicha traza, y otra más modesta, como es la que en esta ocasión nos ocupa (Figura 4).

En cualquier caso, el retablo que preside la capilla de la V.O.T. muestra la implantación del rococó en este género artístico. El signo formal del mismo fue la rocalla, que en este caso se muestra de manera tímida y balbuciente, repitiendo tanto en la mayoría de su decoración, como en su estructura, el modelo del retablo de estípites de la primera mitad del siglo XVIII. Resulta ello característico de los maestros formados en la modalidad del retablo con soporte de estípites y decoración de hoja de cardo. Estos, al implantarse el estilo rococó en Sevilla en la década de los años cincuenta de dicho siglo por Cayetano de Acosta, se convirtieron a la rocalla de manera muy superficial, como resulta evidente en este caso, en el que su autor intentó tal aggiornamento decorativo con unos tímidos golpes de talla rocalla que salpican solo parte del retablo ${ }^{44}$ (Figura 5).

$\mathrm{Su}$ autor, Felipe Fernández del Castillo, es uno de esos maestros de transición entre el retablo de estípites y el rococó. Formado a la sombra de Duque Cornejo, en su larga actividad profesional realizó un importante conjunto de obras, en parte aún conservadas, a las que en esta ocasión hemos de sumar este retablo,

${ }^{41}$ Sancho Corbacho, 1934: 82.

42 Sancho Corbacho, 1952: 285. Herrera García, 2001: 556. Recio Mir, 2000: 187.

${ }^{43}$ De la Peña Velasco, 2019: 3-19.

${ }^{44}$ Sobre el contexto artístico de este retablo, Recio Mir, 2009: 343-ss. 
en el que vemos algunos detalles identificativos de su estilo, como por ejemplo insertar en el centro de las pilastras estípite un medallón oval ${ }^{45}$.

Este retablo se vincula a un camarín, fruto de una reforma de la capilla ya apuntada, al que se accede por una empinada escalera en la que se abre una ventana que lo ilumina. Unos sencillos nervios rematan la bóveda que cubre este espacio, que se abre tanto a la hornacina central del retablo, como a un pequeño hueco que permitía colocar el Santísimo Sacramento en el manifestador que centra su ático. La presencia de este camarín es un ejemplo más de la enorme proyección espacial que alcanzó el retablo en este momento, cuando más frecuente se hizo la apertura de estos espacios ${ }^{46}$.

En cuanto a las esculturas del retablo, hay que indicar que son de la misma modestia que su ensambladura. En tal sentido se combinan los bultos redondos con los relieves. De los primeros encontramos a San Francisco de Asís y al rey San Fernando en las calles laterales y un Crucificado en el expositor del Santísimo, mientras que de la segunda tipología en el ático hay, a los lados, dos tondos con sendas santas y sobre el referido expositor la Estigmatización de San Francisco. También cabe referir en este sentido la vinculación de Fernández del Castillo con el escultor Benito de Hita y Castillo que hizo la imaginería de algunos de sus más importantes retablos ${ }^{47}$, aunque en esta ocasión pensamos, por la referida modestia, que aquel debió de asumir tanto la ensambladura como su imaginería ${ }^{48}$ (Figuras 6-7).

En cuanto a la imagen principal del retablo, aunque en el momento fundacional la V.O.T. rindió culto a la Virgen de los Ángeles, coincidiendo con el estreno del retablo mayor, "en 18 de marzo de 1759 se juntó la Venerable Orden Tercera a determinar qué imagen se había de colocar en el altar mayor de la nueva capilla, camarín y retablo. Si a Nuestra Señora de los Ángeles, que era la antigua y primitiva, o a Nuestra Señora la Divina Pastora. Salió por votos Nuestra Señora la Divina Pastora con 61 votos, y la de los Ángeles con $23 \% 49$.

Resulta sorprendente que de tan democrática manera pasase a presidir el retablo, y, por ende, la propia capilla, la Divina Pastora. Esta imagen fue la primera de tal advocación con la que contó el convento de Capuchinos y, de hecho, esta

45 Sobre Fernández del Castillo, Herrera García, 2001: 531-562.

46 Sobre este asunto remitimos a Recio Mir, 2009: 343.

47 Herrera García, 2001: 531-562.

48 Todo parece indicar que la referida imagen de San Francisco salió a finales del siglo XIX en la procesión de la Divina Pastora, para lo cual se encargó la realización de un paso, la compra de candelabros para el mismo y "hacer un estandarte que presida todos los actos públicos de esta Venerable Orden”. AHPCA, leg. 252, doc. 1, Libro cuarto..., ff. $52 \mathrm{v}-53 \mathrm{r}$. Sobre el referido paso ver también los ff. 65-ss.

49 AHPCA, leg. 323, 1803-1805, doc. 1, Libro primero..., f. 31v. Recogido en De Ardales, 1949: 149. 
capilla, como señaló el padre Ardales, fue el primer templo de Sevilla dedicado a la misma. De ella publicó una fotografía en su monumental monografía ${ }^{50}$.

Esta imagen se realizaría en torno a 1759, cuando ganó el aludido referéndum mariano y, aunque presidía la capilla de la orden, recibió la novena que los capuchinos ofrecieron en su iglesia en honor a la Divina Pastora tanto en 1796 como al año siguiente, precisamente cuando Cristóbal Ramos ${ }^{51}$ se encontraba realizando una imagen propia-financiada por particulares-, que permitiera a los frailes no tener que recurrir a la que era propiedad de los terceros. Esta imagen, a su vez, fue sustituida por la actual, traída de Cádiz por fray Miguel de Otura en $1802^{52}$. De la imagen ejecutada por Cristóbal Ramos nada se sabe, pero la primitiva imagen de los terceros permaneció arrumbada en el recinto después de la conversión de la capilla de la orden en almacén, para ser, posteriormente, trasladada a la localidad de Jerez de la Frontera, donde ha sido transformada en fechas recientes ${ }^{53}$ (Figura 8).

En la actualidad, de nuevo es la Virgen de los Ángeles la que preside el retablo. No obstante, todo indica que no es la primitiva, habiendo sido considerada obra de escuela valenciana de finales del siglo XIX o principios del $\mathrm{XX}^{54}$.

En cuanto a la policromía del retablo, en la actualidad combina el tono dorado de sus elementos decorativos con el marrón de su fondo y con la policromía de las esculturas del mismo. Sin duda, es esa última la más interesante, particularmente por lo que se refiere a la encarnadura y el estofado del aludido San Fernando.

Ahora bien, como ya vimos, González de León señaló en 1844 que esta capilla contaba no con uno, sino con tres retablos. No tenemos otra referencia de estos dos retablos desaparecidos, que serían colaterales y flanquearían al mayor, pero sí sabemos lo que motivó su realización: “en 18 de diciembre de 1763 se determinó hacer dos retablos colaterales para la capilla del Venerable Orden, y colocar en uno a Nuestra Señora de los Ángeles, su primitiva imagen, y en el otro al Patriarca Señor San José, lo que efectuado se estrenó el año de $1765^{\prime 55}$. Por consiguiente, tras ubicar en el retablo mayor contratado en 1759 la imagen de la Pastora, los miembros de la V.O.T. quisieron encargar sendos retablos colaterales en los que rendir culto tanto a su primitiva imagen de la Virgen de los Ángeles como a una de San José. Esos retablos se estrenaron en 1765, por lo que estarían

${ }^{50}$ De Ardales, 1949: 150 y 372, respectivamente.

51 Montesinos, 1986: 56-57.

52 Montesinos, 1986: 372.

${ }^{53}$ Debemos esta última información al amable archivero del convento, Antonio Valiente Romero. En la actualidad recibe culto con el nombre de Virgen de la Salud y Divina Enfermera en la iglesia de San Dionisio.

${ }_{54}$ Martínez Alcalde, 1997: 32.

55 AHPCA, leg. 323, 1803-1805, doc. 1, Libro primero..., f. 32r. 
recubiertos de rocalla y, probablemente, desaparecieron en el proceso de reconstrucción de la capilla de 1891. En cualquier caso, cabe suponer que serían de formato menor, apenas unos marcos para sus imágenes, que complementarían al mayor y enriquecerían este espacio. Nada más dicen las fuentes consultadas, que no aluden a su autor, que quizá pudo ser el mismo que acababa de hacer el mayor, es decir, Felipe Fernández del Castillo, no siendo ello más que una mera hipótesis.

En cualquier caso, merece la pena felicitarnos por la reciente recuperación de la capilla de la que nos hemos ocupado en esta ocasión, con la intención de dar a conocer un reducto del arte barroco sevillano hasta ahora completamente ignorado tanto por el público como por la crítica.

Fecha de recepción: 17 de octubre de 2019

Fecha de aceptación: 23 de febrero de 2020

\section{BIBLIOGRAFÍA}

AA.VV. (2017): Murillo y los capuchinos de Sevilla (cat. exp.). Sevilla: Consejería de Cultura de la Junta de Andalucía.

Cabezas García, Álvaro (2018): "Fasto y pintura en la Sevilla barroca. Las fiestas por la beatificación de San Lorenzo de Brindis en el convento de capuchinos”. En: Anuario de Historia de la Iglesia Andaluza, XI, pp. 353-370. (2019): "Persuasión, arte y devoción. Fiestas en Sevilla por la canonización de dos santos capuchinos". En: Anuario de Historia de la Iglesia Andaluza, XII, pp. 391-402.

De Ardales, P. Juan B. (1949): La Divina Pastora y el Beato Diego José de Cádiz. Estudio histórico. Sevilla: Imprenta de la Divina Pastora.

De la Peña Velasco, Concepción (2019): "Del papel al objeto: el uso de dibujos en la construcción de retablos en la España Moderna”. En: Goya, 366, pp. 3-19.

González de León, Félix ([1844] 1973): Noticia artística, histórica y curiosa de todos los edificios públicos, sagrados y profanos de esta muy noble, muy leal y muy heroica e invicta ciudad de Sevilla y de muchas casas particulares con todo lo que les sirve de adorno artístico, antigüedades, inscripciones y curiosidades que contienen. 2 vols. Sevilla: Gráficas del Sur.

Herrera García, Francisco Javier (2001): El retablo sevillano en la primera mitad del siglo XVIII. Evolución y difusión del retablo de estípites. Sevilla: Diputación Provincial.

Martínez Alcalde, Juan (1997): Sevilla Mariana. Sevilla: Guadalquivir Ediciones.

Martínez del Valle, Gonzalo y Valdivieso González, Enrique (2009): "Murillo y los capuchinos. Procesos decorativos en la iglesia del convento de Santa Justa y Rufina de Sevilla”. En: Estudios de historia del arte, homenaje al profesor De la Plaza Santiago. Valladolid: Universidad de Valladolid, pp. 123-128. 
Matute y Gaviria, Justino (1887): Anales eclesiásticos y seculares de la muy noble y muy leal ciudad de Sevilla, metrópoli de la Andalucía, que contienen las mas principales memorias desde el año de 1701, en que empezó a reinar el rey don Felipe V, hasta el 1800, que concluyó con una horrorosa epidemia, continuación de los que formó don Diego Ortiz de Zúñiga hasta el año de 1671 y siguió hasta el 1700 don Antonio María Espinosa y Cárcel. Sevilla: s. e.

Montesinos Montesinos, Carmen (1986): El escultor sevillano Don Cristóbal Ramos (1725-1799). Sevilla: Diputación Provincial.

Peláez del Rosal, Manuel (ed.) (2006): El franciscanismo en Andalucía. La orden tercera seglar, historia y arte. Córdoba: Asociación Hispánica de Estudios Franciscanos.

Pérez del Prado, Mercedes (2000): La iglesia mínima: el espacio en los templos de las clausuras conventuales sevillanas. Sevilla: Diputación Provincial.

Recio Mir, Álvaro (2000): "El retablo rococó". En: Halcón, Fátima; Herrera, Francisco y Recio, Álvaro: El retablo barroco sevillano. Sevilla: Universidad de Sevilla/Fundación El Monte, pp. 173-236.

(2009): "El brillante final del barroco: el retablo rococó". En: Halcón, Fátima; Herrera, Francisco y Recio, Álvaro: El retablo sevillano desde sus orígenes a la actualidad. Sevilla: Diputación Provincial/Real Maestranza de Caballería de Sevilla, pp. 343-390.

Roda Peña, José (2013): "La capilla de la Venerable Orden Tercera en el convento de San Antonio de Padua de Sevilla: sus retablos mayores y un San Francisco de Asís del escultor Juan de Contreras". En: Laboratorio de Arte, 25, pp. 491-513.

(2018): "Nuevas noticias sobre el retablo de la Venerable Orden Tercera de Santo Domingo de Guzmán, en el Real convento de San Pablo de Sevilla”. En: Archivo Dominicano, 39, pp. 237-263.

Román Villalón, Álvaro (2019): "La Divina Pastora y el modelo pictórico de Tovar”. En: Román Villalón, Álvaro (coord.): En la senda de Murillo: Tovar y la Divina Pastora (cat. exp.). Huelva: Diputación Provincial, pp. 49-135.

Ruiz Barrera, María Teresa (2014): "Bienes del V.O.T. de la Casa Grande de San Francisco de Sevilla en el siglo XVII". En: Laboratorio de Arte, 26, pp. 433-446. (2016): Guía de la capilla de la orden tercera franciscana del antiguo convento de San Pedro de Alcántara. Sevilla: Gráficas Tebas.

Sancho Corbacho, Helidoro (1934): Arquitectura sevillana del siglo XVIII. Documentos para la historia del arte en Andalucía. Sevilla: Laboratorio de Arte/ Universidad de Sevilla, vol. VII.

Sancho Corbacho, Antonio (1952): Arquitectura barroca sevillana del siglo XVIII. Madrid: CSIC.

Valiente Romero, Antonio y Martínez Laguna, Isabel (2008): "La V.O.T. entre dos siglos: la Hermandad de Capuchinos de Sevilla". En: Estudios franciscanos, 444, pp. 1-32. 


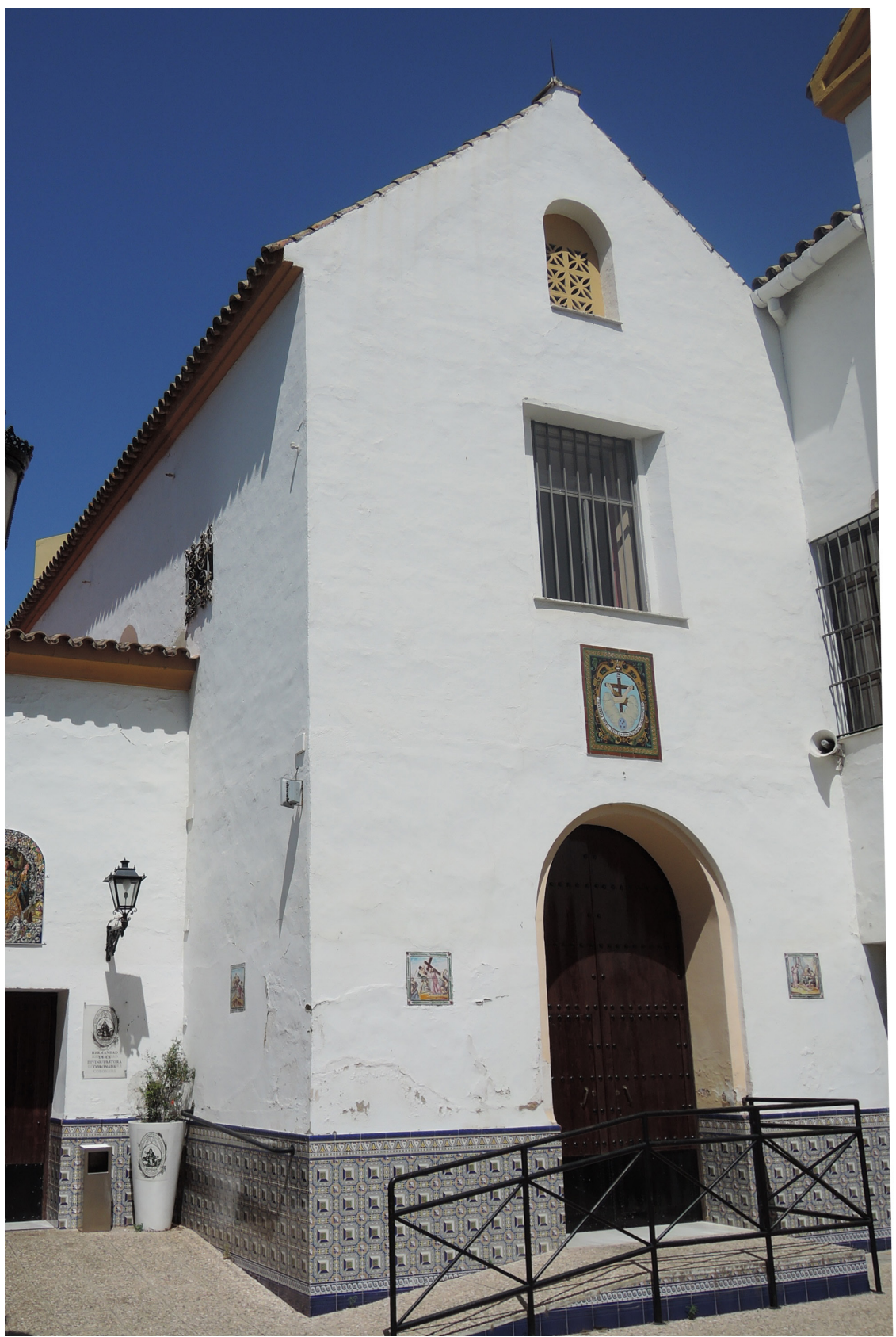

Figura 1. Anónimo, Capilla de la Venerable Orden Tercera del convento de Capuchinos (fachada), siglos XVIII-XX, Sevilla.

LABORATORIO DE ARTE 32 (2020), pp. 271-292, ISSN 1130-5762 e-ISSN 2253-8305 - DOI http://dx.doi.org/10.12795/LA.2020.i32.14 


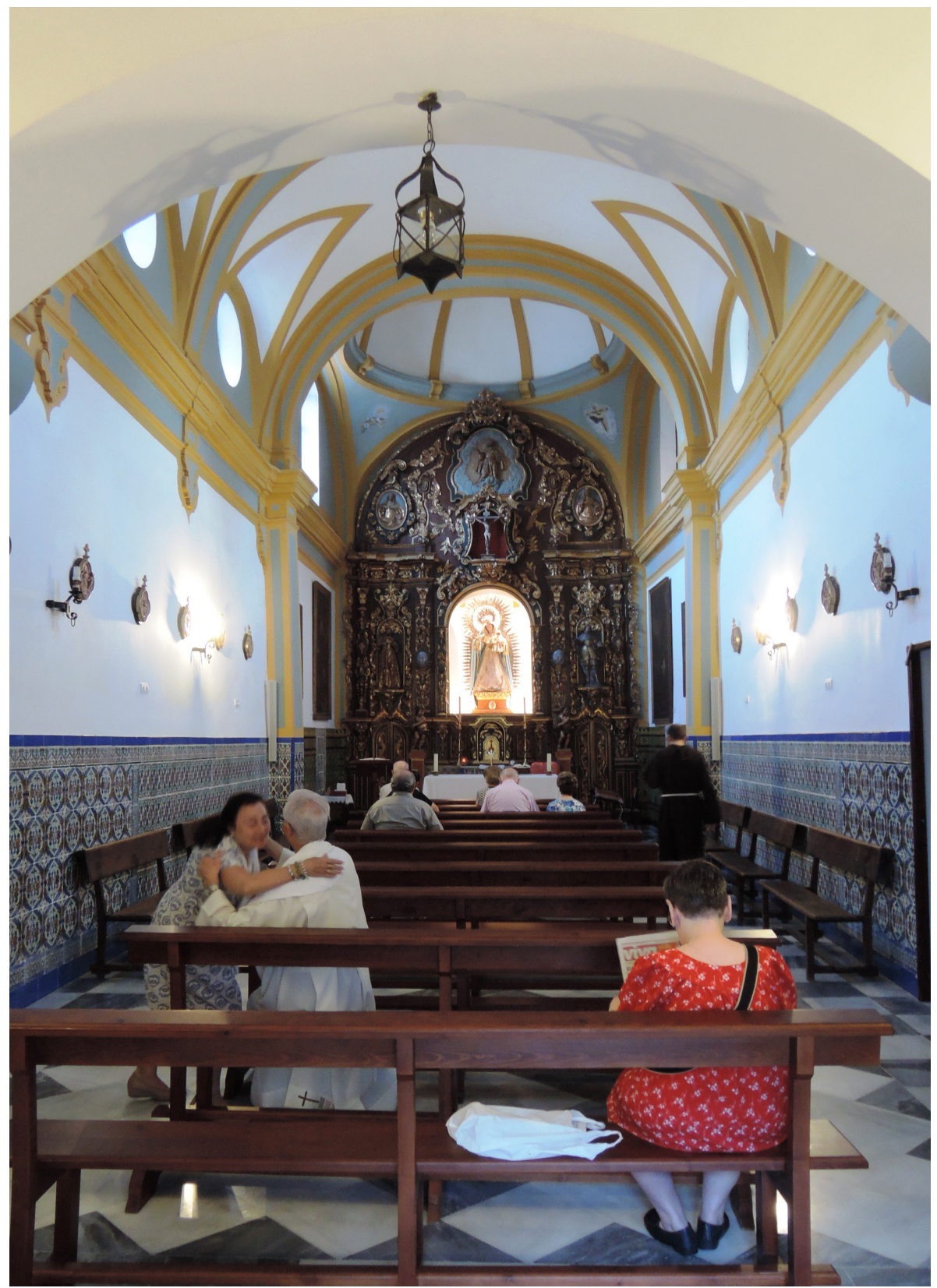

Figura 2. Anónimo, Capilla de la Venerable Orden Tercera del convento de Capuchinos (interior), siglos XVIII-XX, Sevilla. 


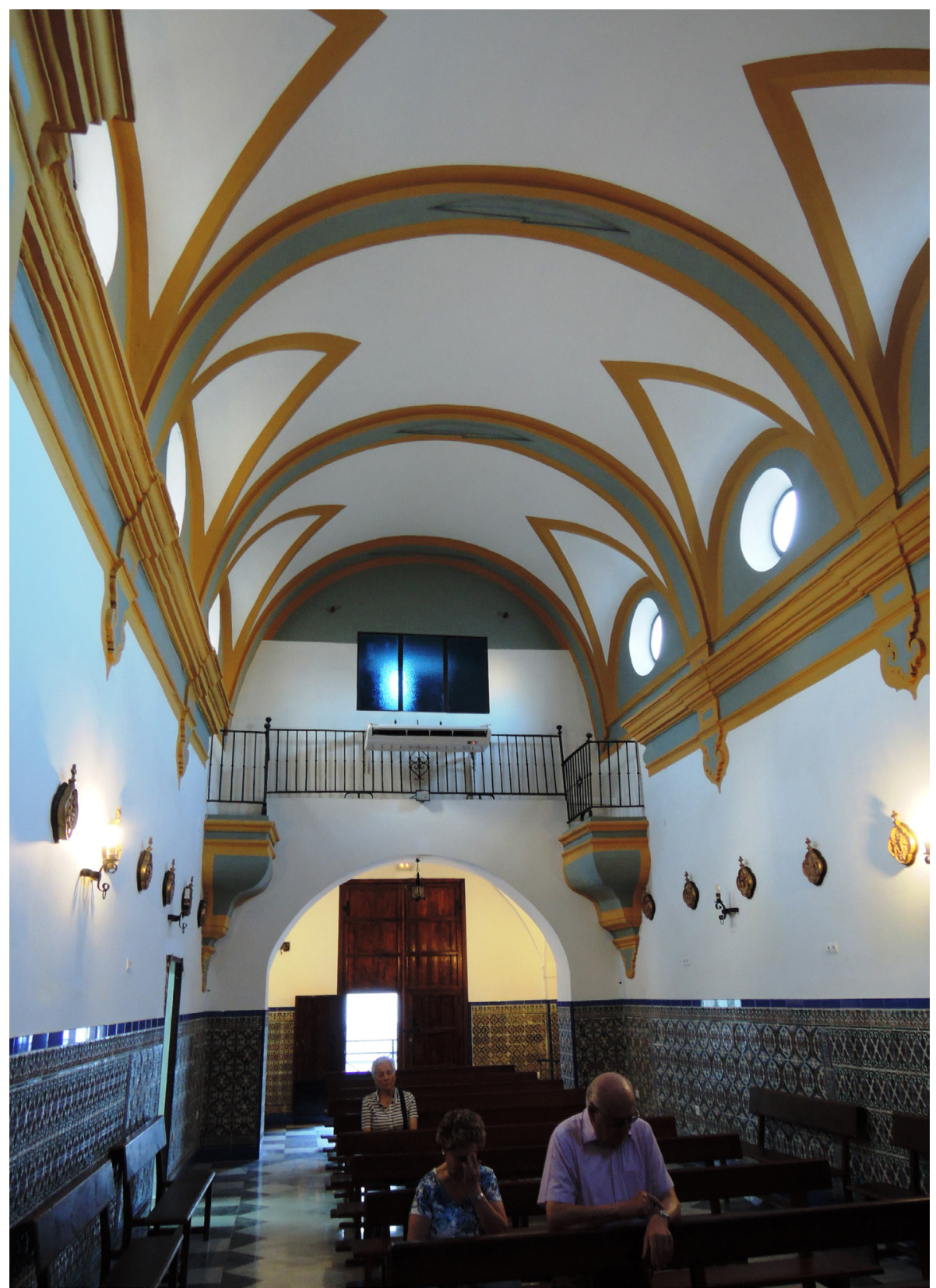

Figura 3. Anónimo, Capilla de la Venerable Orden Tercera del convento de Capuchinos (interior), siglos XVIII-XX, Sevilla. 


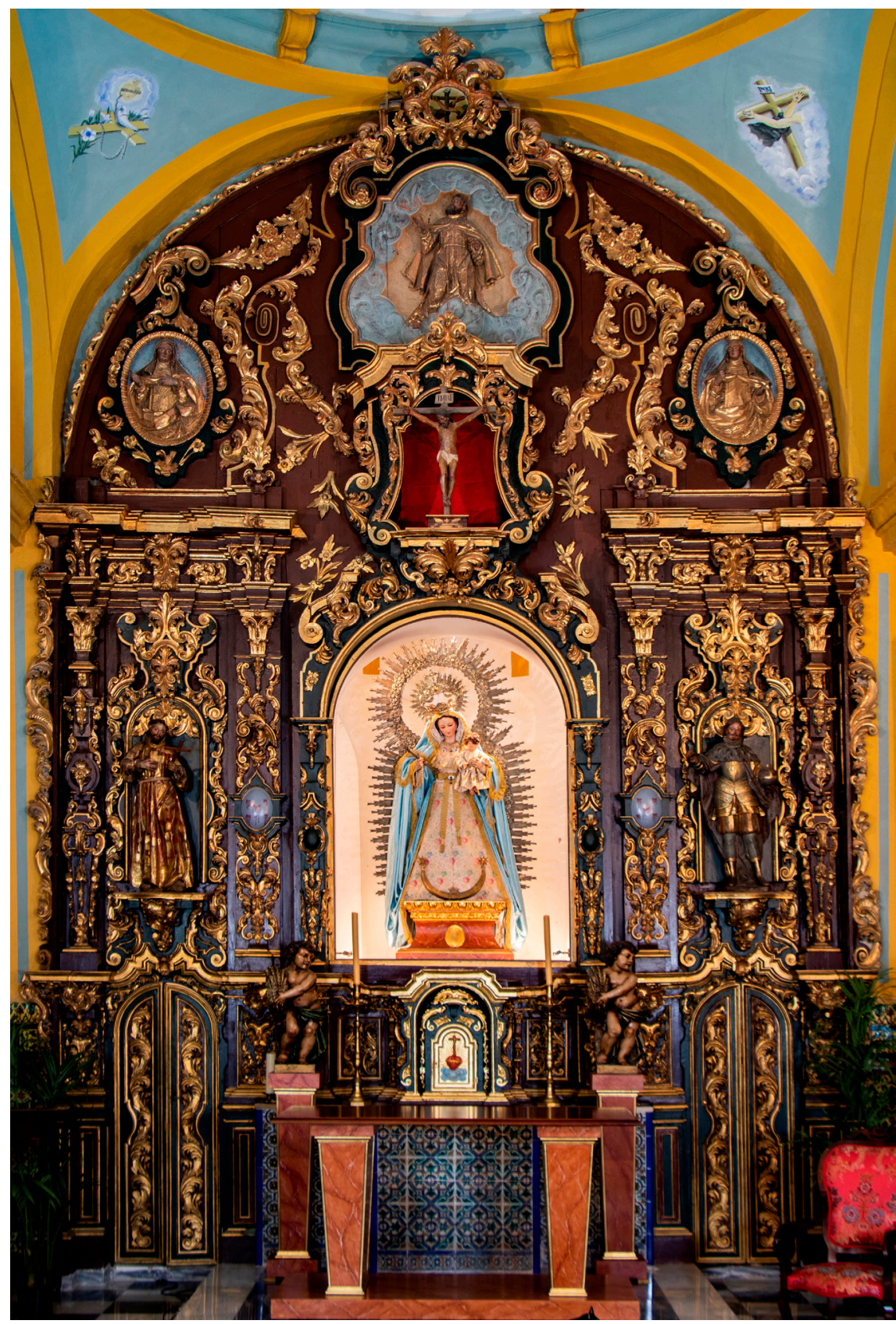

Figura 4. Felipe Fernández del Castillo, Retablo de la capilla de la Venerable Orden Tercera del convento de Capuchinos, 1759, Sevilla. 


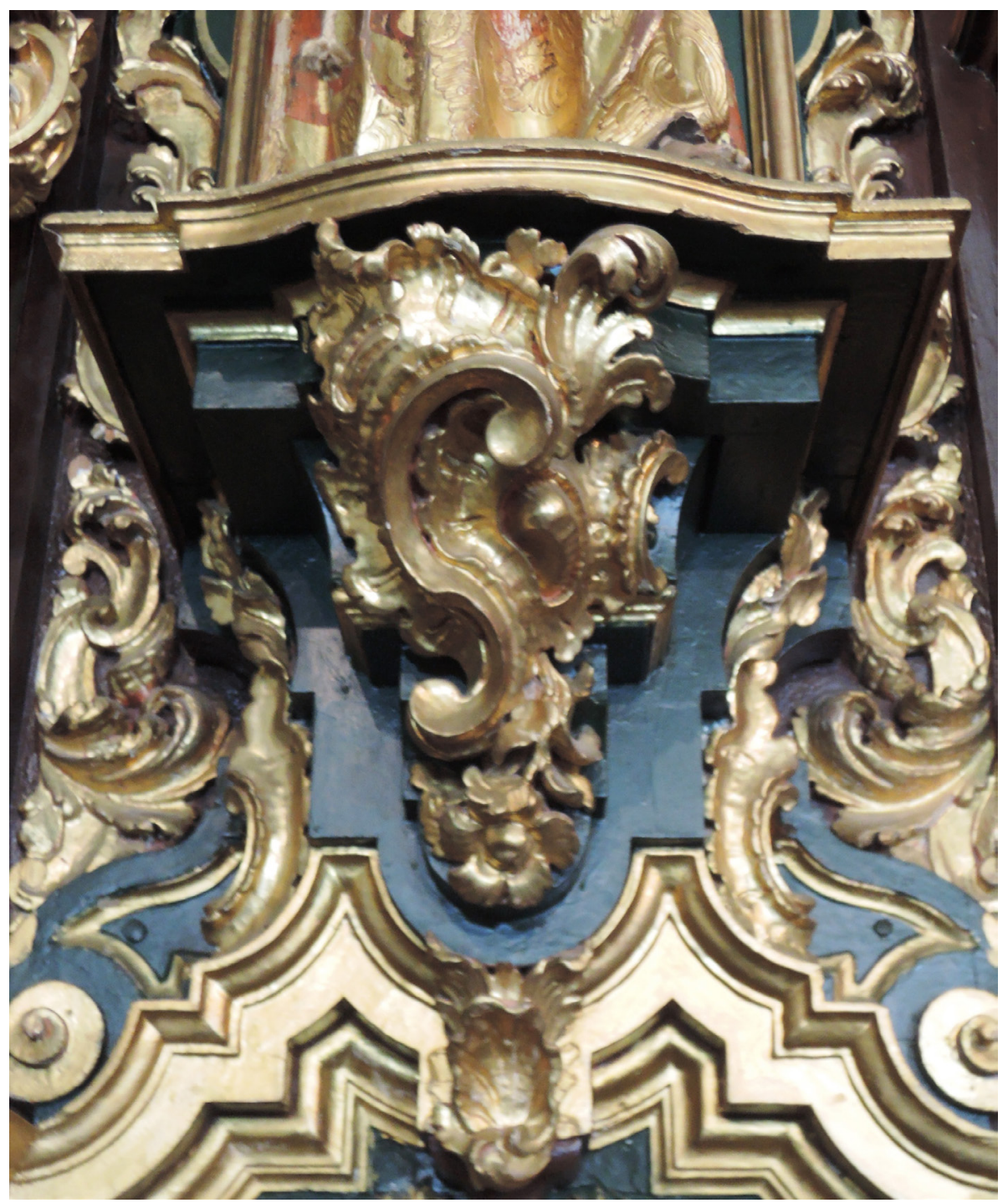

Figura 5. Felipe Fernández del Castillo, Retablo de la capilla de la Venerable Orden Tercera del convento de Capuchinos (detalle), 1759, Sevilla. 


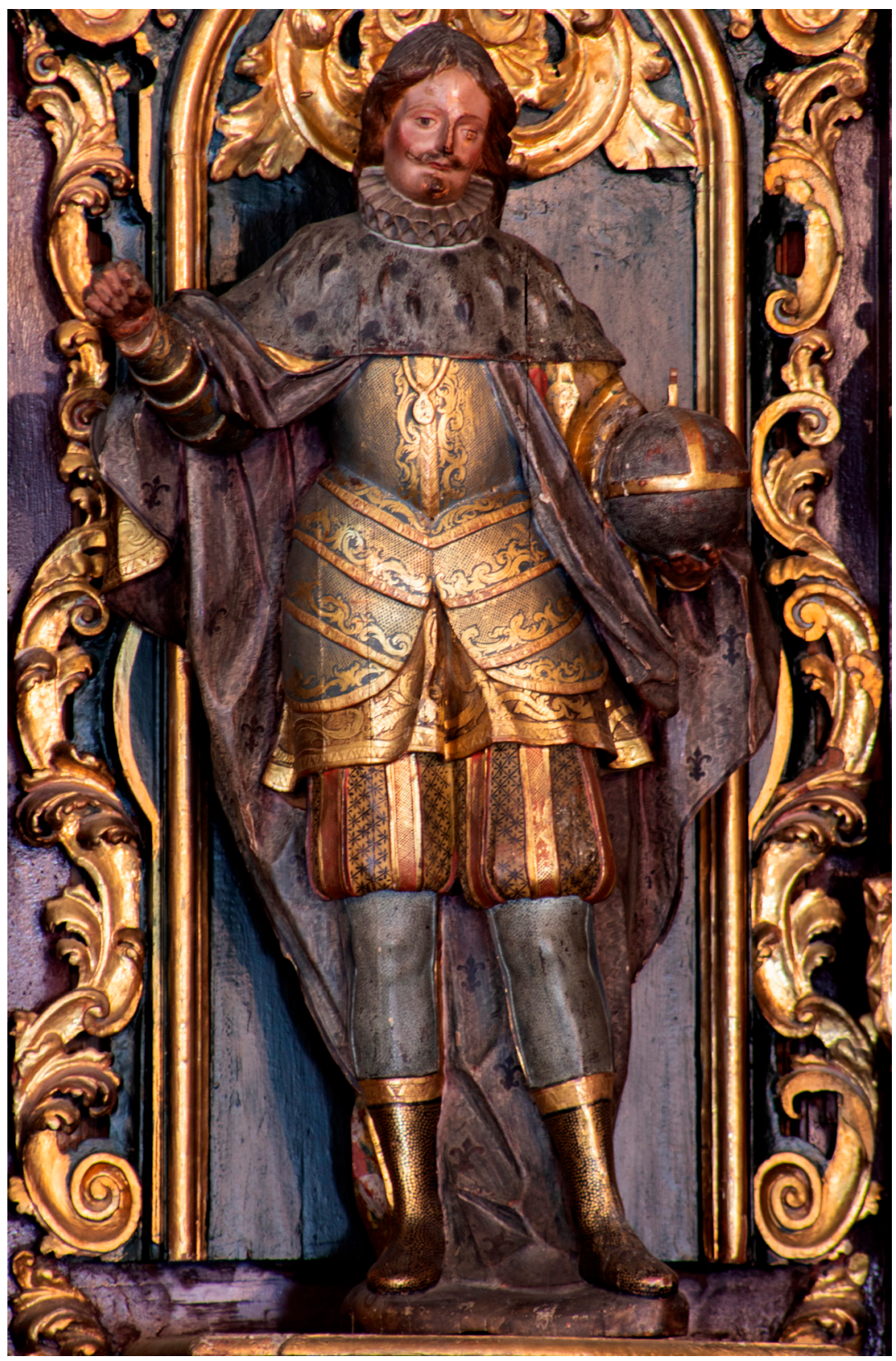

Figura 6. Felipe Fernández del Castillo, San Fernando del retablo de la capilla de la Venerable Orden Tercera del convento de Capuchinos, 1759, Sevilla. 


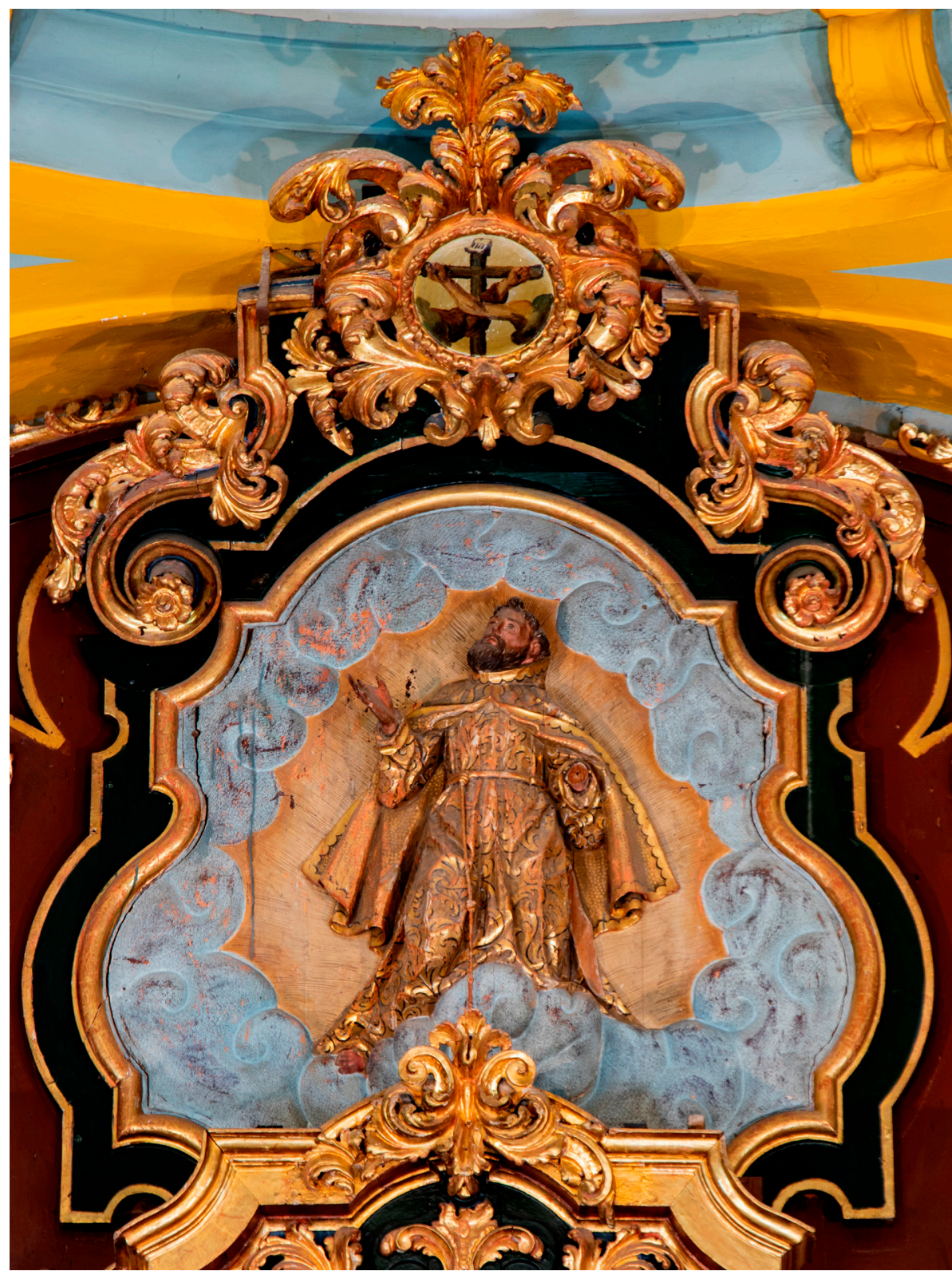

Figura 7. Felipe Fernández del Castillo, Estigmatización de San Francisco del retablo de la capilla de la Venerable Orden Tercera del convento de Capuchinos, 1759, Sevilla. 


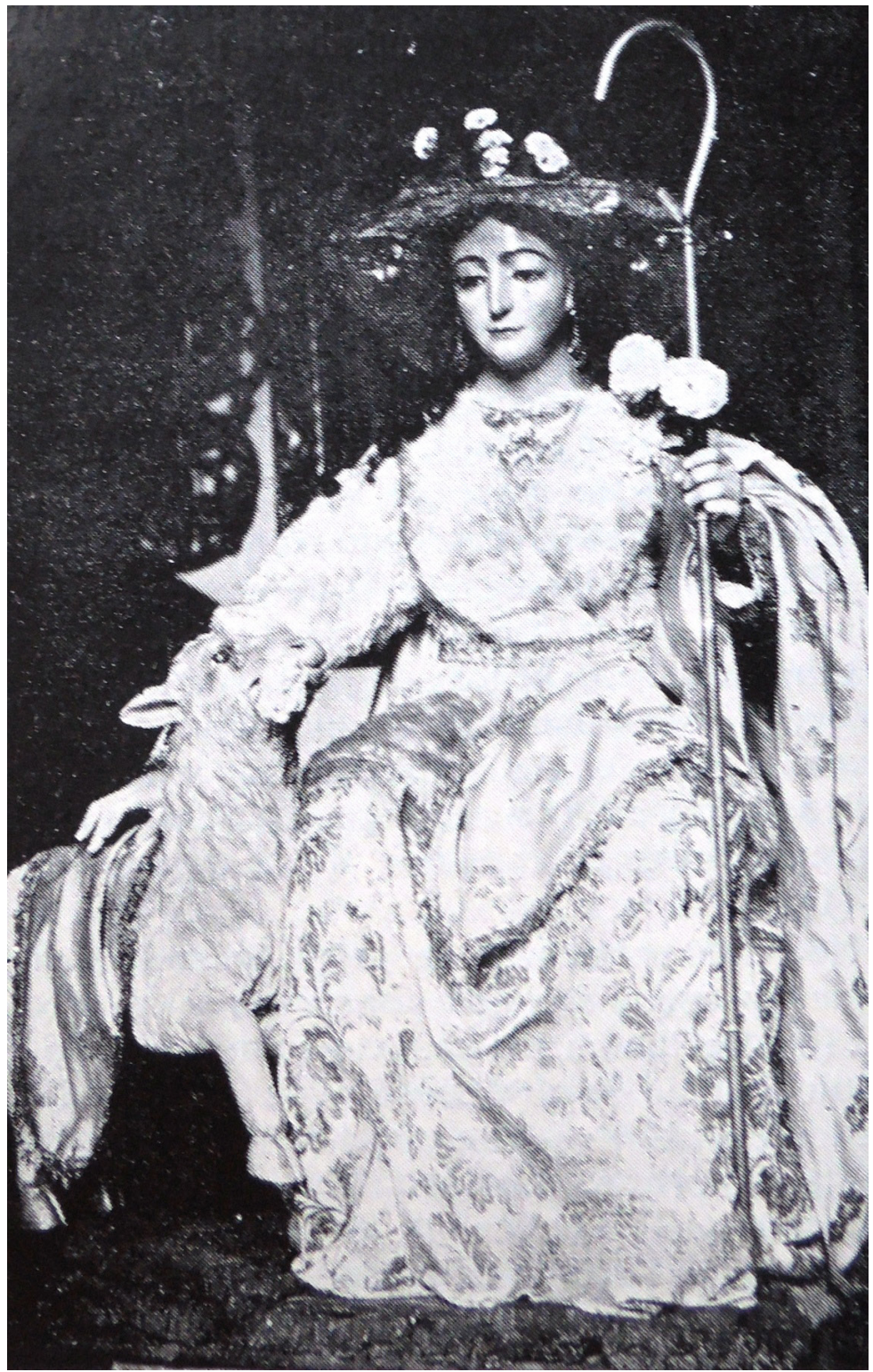

Figura 8. Anónimo, Divina Pastora del retablo de la capilla de la Venerable Orden Tercera del convento de Capuchinos, hacia 1759, Sevilla. 